Preprints of the

Max Planck Institute for

Research on Collective Goods

Bonn 2009/26

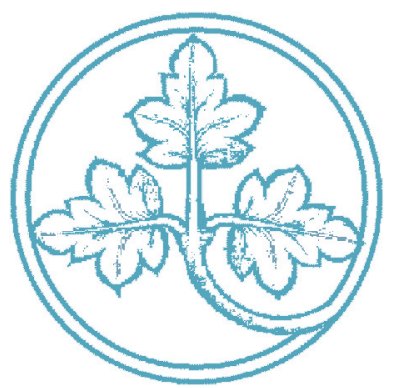

The Transfer of Patents in Imperial Germany

Carsten Burhop

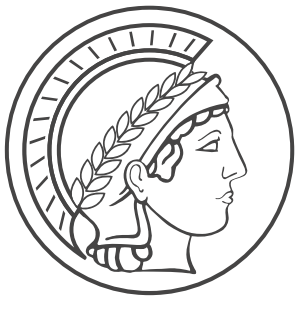




\title{
The Transfer of Patents in Imperial Germany
}

\author{
Carsten Burhop
}

August 2009 


\title{
The Transfer of Patents in Imperial Germany ${ }^{*}$
}

\author{
by
}

\section{Carsten Burhop ${ }^{\ddagger}$}

\begin{abstract}
We describe the transfer of patents in late 19th- and early 20th- century Germany using a new and comprehensive database containing information on about 20,000 transactions. The number of transactions shows an upward trend, in total numbers and as a share of patents in force. In total, about eight percent of patents were transferred at least once during their existence. Many transactions involved the transfer of patents with an above-average quality from individual inventors to firms and to newly-created - 'entrepreneurial' - firms. In addition, valuable patents were transferred between firms. About two-thirds of all transfers occurred during the first three years of a patents' existence, giving the new owner potentially a long period of patent protection.
\end{abstract}

JEL-Classification: N73, O34

Keywords: Economic History; Germany; pre-1913; Patents; Technology transfer.

* I would like to thank my research assistants Marina Boland, Kathrin Datema, Miriam Knoop, Katia Kube, and Juliane Schrader, who put more than 3,000 hours of work into the construction of the data set. Financial support by the Deutsche Forschungsgemeinschaft is gratefully acknowledged. Many helpful comments from Christoph Engel, Sybille Lehmann, Thorsten Lübbers, Tom Nicholas and seminar participants at the University of Oxford, University of Hohenheim, University of Warwick, University of Cologne, Otto Beisheim School of Business Vallendar, the Max Planck Institute for the Study of Society, as well as participants of the 2008 Meeting of the Economic History Association, the 2008 Conference of the Verein für Socialpolitik, and the Conference in Honour of Rainer Fremdling substantially improved the paper. Brian Cooper edited my use of a foreign language. However, all remaining shortcomings are the sole responsibility of the author.

* Max-Planck-Institut zur Erforschung von Gemeinschaftsgütern, Kurt-Schumacher-Straße 10, 53113 Bonn, Germany, Email: burhop@coll.mpg.de 


\section{Introduction}

During the 1990s and early 2000s, technology-related payments and receipts - e.g., licence fees and patent royalties - increased sharply in OECD countries. In 2005, the average value of imports and exports of technology equalled about 0.55 percent of GDP. This is, compared to the value of trade in goods and services of about 25 percent of GDP in 2005, a small, but still significant amount, representing a value of circa $\$ 190$ billion. This exchange of technology should make all participants better off since standard arguments as in the case of trade in goods and services are at work: division of labour and specialisation of production foster growth and efficiency. Beyond standard gains from trade arguments, however, trade in technology has a significant additional effect on welfare. The public-good character of innovations allows multiple users to combine research and development (R\&D) efforts and to employ the same innovation. Consequently, trade in technology enables producers to draw the best innovation from a larger pool of inventions. This, in turn, shifts the production possibility frontier of all participants outwards and increases per capita income (Spulber, 2008). This argument also applies to technology transfer within countries. A thriving exchange of technology within a country should increase per capita income and productivity.

Historical studies of within-country technology transfer and studies of patent transfers within countries mainly use U.S. data. Khan and Sokoloff (1993, 2004), Khan (1995) as well as Lamoreaux and Sokoloff $(1999,2001)$ show that a patent market already existed in the U.S. during the mid-19 ${ }^{\text {th }}$ century. In particular, Lamoreaux and Sokoloff $(1999,2001)$ illustrate that one-third of U.S. patents were fully or partially assigned after issue, i.e., transferred, by the inventor. ${ }^{1}$ During the 1870 s, inventors commercialised their ideas themselves, but at the same time often granted geographically bounded licenses to producers in distant regions. At the turn of the century, innovation and commercialisation were increasingly separated activities and specialised inventors sold or licensed their patents to firms (see, e.g., Lamoreaux and Sokoloff, 2000, for a case study of the American glass industry). This development cumulated in the outsourcing of some research tasks and the close collaboration between in-house researchers of manufacturing firms and specialised free-standing research laboratories (Mowery, 1983). The complementarity of outside inventions and in-house research and the transfer of technology over larger geographic distances was also highlighted by Nicholas (2009).

Our paper offers new evidence of technology transfer outside the United States by analyzing the patent transfer register of Germany's Imperial Patent Office (see Section III). We show that many patents were transferred in Germany between the enactment of the first national patent law in 1877 and the Great War. In addition, transfer activity grew over time, in absolute numbers as well as in relation to the number of patents in force. Dominant actors were firms: about two-thirds of all patents transferred were transferred to firms. In contrast, only about one-third of transferred patents originated in firms. Moreover, firms were quite good in

1 Over the course of the 20th century, the relative size of the U.S. patent market shrank and only one in seven patents issued after 1982 was assigned (Serrano, forthcoming). 
screening successful patents and received - on average - patents with a high quality. About two-thirds of all transfers were arranged within the first three years after the issue of a patent, giving potentially a long period of monopoly protection to the acquirer. Moreover, we show that only a small fraction of the transfers were of administrative nature. If, for example, a firm changed its legal form, all patents of the firm were transferred from the old to the new legal entity. Yet, about 85 percent of all transfers potentially were related to market activity, i.e., selling and buying of technology. ${ }^{2}$

Germany is a particularly promising area of research for several reasons (see Section II for details). First of all, professional R\&D management by corporations emerged at about the same time in Germany as in the U.S. and much earlier than in most other countries. This is reflected, for example, in the foundation of corporate R\&D laboratories in the German chemical and pharmaceutical industry during the 1870s and 1880s (Wimmer, 1994; Murmann, 2006). ${ }^{3}$ Second, the German patent law enacted in 1877 most likely fostered the development of a market for technology. German patents represented secure property rights, since the patent office thoroughly evaluated the innovativeness of the patent. ${ }^{4}$ Moreover, patent infringements were mostly settled between the publication of a patent application and the issue of the patent (Lübbers, 2009). Furthermore, a patent had to be put into use within three years after issue, setting a strong incentive for small inventors to transfer their patent to a firm. In addition, comparatively high patent fees were an incentive for small inventors to transfer their patents. Finally, patents were issued to the person registering the patent at the patent office. Consequently, inventions made by employed inventors were registered by the firms employing them and not by the employees (Burhop and Lübbers, 2008). ${ }^{5}$

Our research potentially offers a microeconomic foundation for knowledge spillovers highlighted in the recent literature. In Germany, inter-industry knowledge spillovers between technologically, economically, and geographically related industries were a major source for

2 So far, only scattered evidence from archival sources shows that a market for patents existed at the turn of the 20th century in Germany. For example, on 1 August 1908, the Darmstadt-based pharmaceutical firm E. Merck and Dr. M.K. Hoffmann, a chemist from Leipzig, sealed a contract regulating the transfer of patent-number 185,600. After signing the contract, Merck paid a fixed amount of 500 Marks to Hoffmann. Moreover, after successful clinical trials and in case of a successful market launch, the inventor would receive another 500 and 400 Marks, respectively, as well as a profit share of 20 percent. Merck Record Office, R 1 / 42. Burhop (2009), Wimmer (1994), and König (2007) contain a number of similar case studies from the pharmaceutical, chemical, and electrical engineering industries.

3 Research laboratories were also established in the U.S. chemical and pharmaceutical industry at the same time, whereas the British chemical and pharmaceutical industries lagged behind. See Church / Tansey (2007) for Britain and Houshell / Smith (1988) and Swann (1988) for the United States. In the electrical engineering industry, centralized R\&D facilities were set-up during the inter-war period, but decentralized research was conducted during the pre-1913 period in the U.S. and Germany (see Erker, 1990).

4 The security of property rights was also a major pre-condition for the emergence of the American patent market, see Khan (1995) on this point.

5 Thus, the German patent transfer data do not include the transfer of patents within firms and potentially give a much more precise picture of technology market transactions than U.S. data. Khan (2005, chapter 2) reviews the patent systems of the U.S. and the main European countries. In the U.S., a stringent technical examination of the patent and the issue of the patent to the true inventor was the norm. There were no patent fees in the United States. Britain, on the other hand, did not implement a technical examination of patents and raised patent fees. The fees for the maximum length of protection were 154 Pounds (about 3,100 Marks), substantially less than in Germany. 
further innovative activity during the German industrialisation (Streb et al., 2006). In addition, the existence of knowledge spillovers between the textile and the dyestuff industry has been shown: innovations in one branch Granger-caused output and innovations in the other branch (Streb et al., 2007). Furthermore, a positive impact of intra- and inter-industry knowledge externalities for the innovative activity of firms located in Baden, a small state in south-west Germany, has been detected (Baten et al., 2007). In summary, the evaluation of patent data using time-series and spatial econometric methods reveals a significant impact of knowledge spillovers on economic growth and innovation in Germany at the turn of the $20^{\text {th }}$ century. Yet, these findings do not reveal how technology spilled over from one agent to another. The transfer of patents could be one channel.

The current study also relates to Serrano's (forthcoming) work, who investigates the modern U.S. patent market from a theoretical and empirical perspective. He assumes that patents are transferred to agents possessing better complementary assets to exploit the patent than the current patent owner. A main prediction of the model is a negative relationship between the age of a patent and its trading probability. In addition, a patent transfer is considered to be a reliable signalling device indicating the value of a patent. Consequently, a transferred patent was screened by the new owner and should thus have a higher quality than the average patent. It turns out, that our historical data support the major assumption and some results of Serrano's model.

\section{Historical and institutional background}

Germany's rise to one of the leading industrial economies during the second half of the $19^{\text {th }}$ century is often ascribed to its ability to innovate. Indeed, the growth of total factor productivity (TFP) accounts for about one-quarter of the output growth in German industry between 1851 and 1913. Moreover, TFP growth in the industrial sector accelerated substantially during the 1890s and the structure of the economy changed such that industries with higher productivity growth increased their employment share (Burhop / Wolff, 2005). In particular, the success of Germany's chemical and electrical engineering industries was connected to the inventions made. In turn, the inventive activity of the modern sector was fostered by the highquality of Germany's system of higher education, the substantial governmental support for science, and the emergence of industrial research laboratories (Landes, 1999: 290-291; Cameron / Neal, 2003: 242-243). 


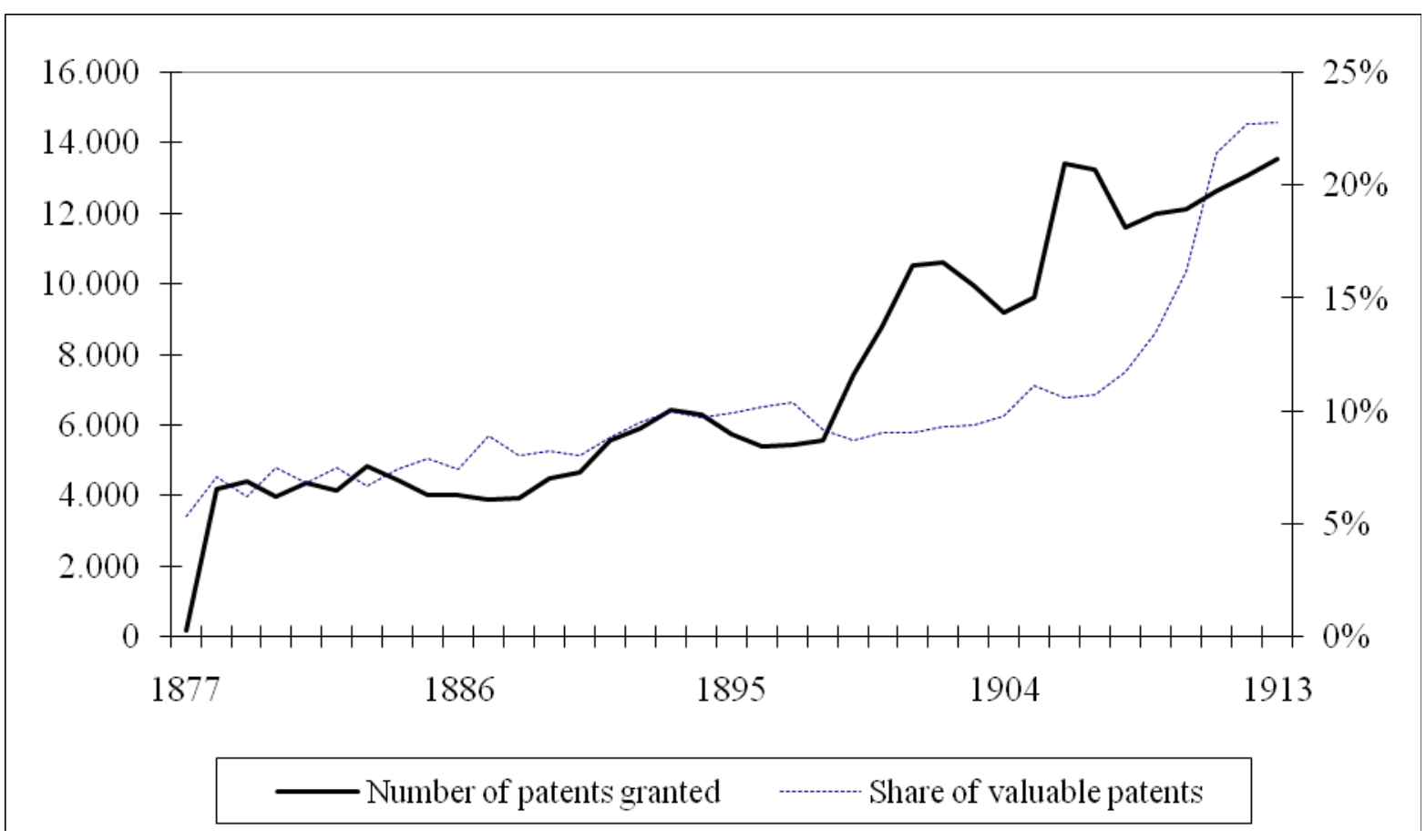

Figure 1: Sources: Kaiserliches Statistisches Amt, Statistisches Jahrbuch für das Deutsche Reich (various issues) for the number of patents granted; Streb / Baten (2007: 355) for the share of valuable patents.

The increasing innovative capacity of the German economy is, for example, reflected in the rising number of patents granted as well as in the rising number of economically valuable, long-living patents granted (see Figure 1). ${ }^{6}$ The total number of patents granted per year varied between 4,000 and 5,000 during 1877-1890. Thereafter, the number of patents granted per year increased to about 10,000 . After 1906, the number of patents granted per year varied at around 13,000. The share of long-living patents in total patents granted varied between six and eight percent until 1886. Thereafter, their fraction was about eight to ten percent until 1904. Subsequently, their share increased to more than ten percent. ${ }^{7}$ In summary, the number of patents as well as the average quality of patents increased over time.

Thus, the number of patents available for transfers increased over time. Yet, essential for the emergence of a market for technology are secure property rights. ${ }^{8}$ The security of intellectual property rights was relatively high in Germany from 1877 onwards. First of all, each patent application was assessed by the patent office regarding novelty, potential conflicts with existing patents, and technical feasibility. In a next step, the patent application was published and

6 During the early 2000s, Jörg Baten and Jochen Streb collected data about all patents issued in Germany between 1877 and 1913 and in force for at least ten years. They label the latter as 'valuable patents' since the owner of such a patent has already paid 2,300 Mark as patent fees to keep the patent in force.

7 This development is most likely due to the exemption of patent fees during the First World War as well as to the substantial decline of real patent fess during the German hyperinflation of the early 1920s, which makes the identification of valuable patents on the basis of a patents' lifetime much more complicated (Streb / Baten, 2007: 256-258).

8 Khan and Sokoloff (1993) and Khan (1995) highlight this point for the emergence of a patent market in the United States during the first half of the 19th century. 
an appeal against the patent could be made during a period of six weeks. Only if no convincing appeal was made, the patent was finally granted (Seckelmann, 2006: 257-260). Between 1877 and 1913, the total number of patent applications was 765,653. Most applications did not pass the technical examination by the patent office and only 304,057 applications were published. 11,701 published applications were appealed and not granted. Of the patents granted, only 877 were repealed by the patent office later on. Moreover, between 1902 and 1913, only 359 cases of patent infringements were put to trial. In about half of those cases, the patentee won the case. Comparing the number of patents repealed or the number of patent infringements with the number of patents granted shows that patents were indeed a very secure property right (see Lübbers, 2009, for details). Consequently, a large number of secure intellectual property rights were available for transfers.

Furthermore, the German patent law stimulated the transfer of patents, since the law stipulated the application of a patent within three years after issue. If the patent was not put into use by the patentee, the patent office could annul the patent. Moreover, the patentee had to pay an annual fee to keep the patent active. This fee was 50 Mark for the first year and 50 Mark for the second year of protection, but thereafter the fee increased substantially by 50 Mark per year up to the maximum annual fee of 700 Mark for the $15^{\text {th }}$ and final year of protection. Thus, the cumulated fee over the maximum period of patent protection of 15 years was 5,300 Mark, about 6.5 times the annual per capita income in 1913.

\section{Data sources and descriptive statistics}

Patent transfer data were published annually by Germany's Imperial Patent Office for the years 1884-1887 and 1889-1913. ${ }^{9}$ We manually collected transfer data using the annual "Verzeichnis der vom Kaiserlichen Patentamt im Jahre [...] erteilten und noch in Wirkung stehenden Patente". This annual informs about the transfer of a patent and includes information about the patent number, the technology class, and the name and place of residence of the new patent holder. We utilized the patent number to determine the year of issue of the patent and but only for a random sub-sample of 4,025 of the transferred patents - the name and place of residence of the original patent holder. Moreover, we employed the patent number to determine the total lifetime of the patent. This task was fulfilled using the annual register of valid patents. We screened the annual patent yearbook only until 1913, since patent fees were lifted during World War I and the real patent fees were very low during the hyperinflation of the early 1920. Thus, patent renewal costs were close to zero after 1913 and patent renewal data lose much of their information about patent value.

9 For the period $1877-83$, only data referring to the patents transferred between 1877 and 1883 and still in force in March 1884 are available. Moreover, patent transfer data are unavailable for 1888 since the patent transfer register was not published in this year. Finally, the patent office stopped the publication of the transfer register at the outbreak of World War I. Therefore, transfer data are unavailable from 1914 onwards. 
While the data contain a lot of information, four potential shortcomings should be kept in mind. First, the annual register of patent transfers did not contain all transferred patents, but only those for which the change in ownership occurred some time after issue. More specifically, a patent transfer sealed between issue of the patent and the publication of the next patent yearbook by the patent office was not listed in the transfer register. For example, a patent issued on 1 July 1900 and transferred before the publication of the next patent yearbook - in March 1901 - would not be included into the register of transferred patents. Consequently, transfers at issue, which were important in the U.S., are not covered by our data. Yet, inventions of employed inventors, which account for a large part of transfers at issue in the U.S., were registered by the firms employing the inventor in Germany. Thus, transfers at issue should be less relevant in Germany. ${ }^{10}$

The second drawback of our data set is the fact that not all transfers registered by the patent office were transfers caused by economic motives: patents were regularly transferred if a change in the legal form of the patent holder occurred. For example, the German electrical engineering firm Siemens changed the legal form twice - first from a general partnership (Offene Handelsgesellschaft or OHG) to a limited partnership (Kommanditgesellschaft or $\mathrm{KG}$ ) and then to a joint-stock company (Aktiengesellschaft or AG) - and each time all patents were transferred to the new firm. Such patent transfers are, however, not caused by an economic motive related to the patent itself. Consequently, we coded it as a transfer due to change in the legal form of enterprise. Furthermore, transfers from an individual to another individual as an inheritance were registered by the patent office. Such transfers are not related to market transactions of patents and are coded as an inheritance.

Third, we have to address a standard issue in empirical investigations of patents, namely the question about the economic value of patents. In an ideal world, we would like to know the patent-specific social and private returns of a patent. However, this information is generally unavailable. Standard proxies for the value of patents are the number of years a patent is in force, the patent fees paid, and the number of citations received (Griliches, 1990; Grupp et al, 2002; Metz / Watteler, 2002). Citations are unavailable for late $19^{\text {th }}$ - and early $20^{\text {th }}$ - century German patents. The design of patent fees implies that the costs of keeping a patent in force for a fixed number of years after a transfer depends on the number of years the patent was in force before the transfer. If, for example, a patent was kept in force for a period of five years after the transfer, the cumulated fee for a patent transferred three years after issue was 1,250 Marks, whereas the cumulated fee was 1,750 Mark if the patent was transferred five years after issue. This suggests that the cumulated fee paid after the transfer is the better proxy of the lower bound of the option value of transferred patents.

10 Lamoreaux / Sokoloff (1999: 26) present data for U.S. patent transfers for patents granted in 1870/71, 1890/91, and 1910/11. 34 percent out of a sample of 4,036 patents were transferred after issue, 39 percent were transferred at issue, and 27 percent were never transferred. The high ratio of patent transfers at issue suggests that many patents were transferred from employed inventors to their employers. 
Censoring is a final drawback of our data. Patent transfer data were not published for the years after 1913. Consequently, statements regarding the fraction of patents issued during a year and transferred later on are downward biased for all patents granted from 1899 onwards since these patents could have been transferred in or after 1914, since the maximum lifetime of a patent was 15 years. In practice, about 80 percent of all patent transfers were sealed during the first four years after issue. Therefore, censoring becomes problematic for patents issued during and after 1910. In the econometric analysis in Section IV, we address the problem of censoring and the problem of zero-fees during and after World War I by including a yearof-grant fixed effect.

During 1884-87 and 1889-1913, 219,513 patents were granted in Germany. Out of those patents, at least 18,135 patents ( 8.3 percent) were transferred at least once. Therefore, the rate of patent transfers in late $19^{\text {th }}$ - and early $20^{\text {th }}$ - century Germany is close to the rate of patent transfers in the U.S. between 1983 and 2002 of 13.5 percent (Serrano, forthcoming). However, the German patent market was much less liquid than the historical U.S. patent market. Data collected by Lamoreaux and Sokoloff (1999: 26) for a sample of patents issued in 1870/71, 1890/91, and 1910/11 show that 34 percent of the patents were assigned (i.e., transferred) after issue.

Moreover, many German patents were transferred more than once: 2,265 patents were transferred twice, 230 patents were transferred three times, and 27 patents were transferred four times. Therefore, the probability that a patent was transferred twice was larger than the probability that a patent was transferred once ( 12.5 vs. 8.3 percent). This gives support to one of Serrano's (forthcoming) theoretical propositions and to his empirical results based on data from the late $20^{\text {th }}$ - century United States.

Figure 2 shows the evolution of the number of transactions over time. The total number of transactions carried out during 1884-87 and 1889-1913 was 20,657. Moreover, at least 505 transactions were accomplished between 1877 and 1883 . The number of patent transfers fluctuated around 300 per annum until 1893. Thereafter, the number of annual transactions increased substantially, surpassing 1,000 in 1904. The number of transfers peaked in 1911 with 1,607 transactions. The number of patent transfers did not only increase in absolute terms, but also in relation to the number of patents in force. The transfer rate - i.e., the number of transferred patents divided by the number of patents in force during a year - fluctuated between 1.8 and 2.3 percent until 1893 . Thereafter, the ratio was always higher than 2.4 percent, with a peak of 3.8 percent in 1904 . 


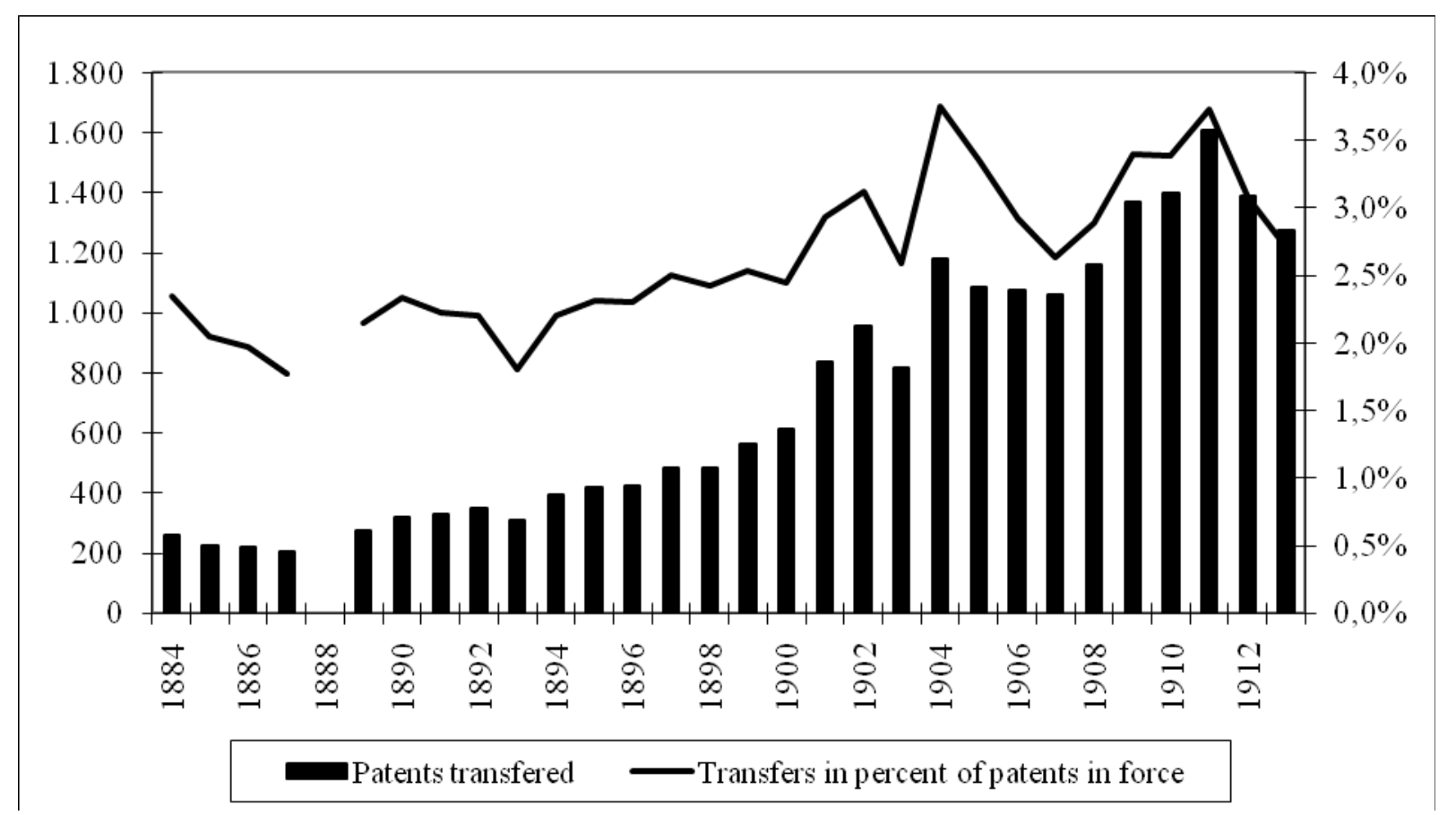

Figure 2: Patent transfers in Imperial Germany, 1884-1913

Source: Patent transfer data base.

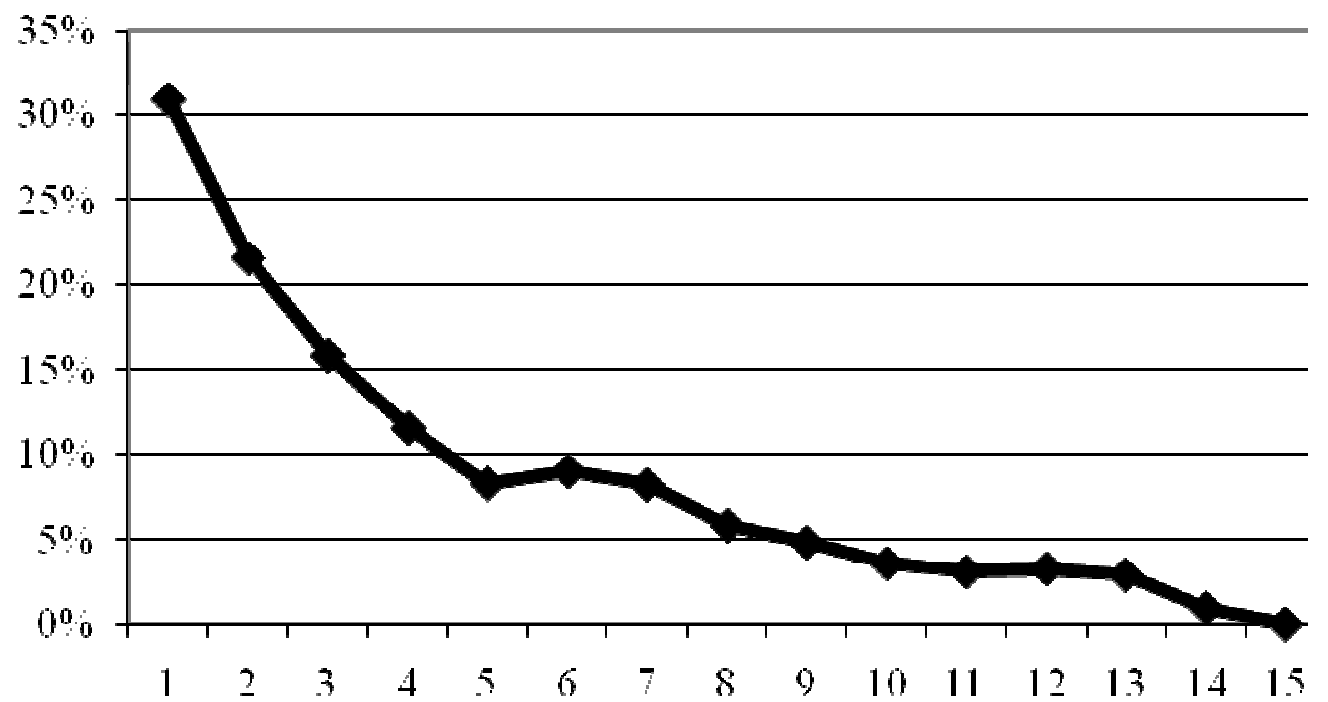

Figure 3: Number of years passed between issue and transfer of a patent.

Source: Patent transfer data base. 
Most patents were transferred during the early phase of its existence, see Figure 3: 30.9 percent of all transfers were registered during the first year after issue, 21.6 percent of all transfers were registered during the second year after issue, and 15.9 percent of all transfers were registered during the third year after issue. Thus, 68.4 percent of all transfers were registered during the first three years after issue of the patent. At least two arguments can be put forward to explain this finding. First, the patent law dictated that all patents had to be put into use within three years after issue. Consequently, inventors without capacities to use a patent themselves - for example individual inventors or university professors - had a strong incentive to sell it within the first three years after issue. Second, Serrano's (forthcoming) model predicts that the trading probability of a patent is declining in its age, since the number of years with patent protection and therefore the expected present value of the monopoly rent is declining in the age of the patent. Consequently, if a patent has an economic value, it should be put into use as early as possible.

Furthermore, the number of patents traded was clustered in few technology classes: ${ }^{11}$ more than 22 percent of all transfers were registered in the four most active technology classes. ${ }^{12}$ The largest number of transfers was registered in electrical engineering (technology class 21) with 2,405 transfers between 1877 and 1913, equal to 14.1 percent of all patents granted in this technology class during this period. Other active technology fields were printing machines and typewriters with 848 transfers (13.6 percent of all patents granted; technology class 15), mechanical metal processing (754 transfers; 9.7 percent; technology class 49), and chemical processes and drugs, excluding dyestuffs (752 transfers; 8.4 percent; technology class 12). Firms from the dyestuff industry, which was prominent for the early establishment of in-house R\&D capacities, were less active on the market for technology. Only 396 patent transfers were registered in technology class 22 (dyestuffs), just 7.3 percent of the number of patents granted.

11 The German patent office allocated a patent technology class to each patent according to the industry of use.

12 This finding is similar to the modern U.S., where Serrano (forthcoming) found a high trading activity in drugs and pharmaceuticals and a low trading activity in mechanical engineering. Moreover, similar findings are a standard result for empirical investigations of the licensing market (Anand and Khanna, 2000). 


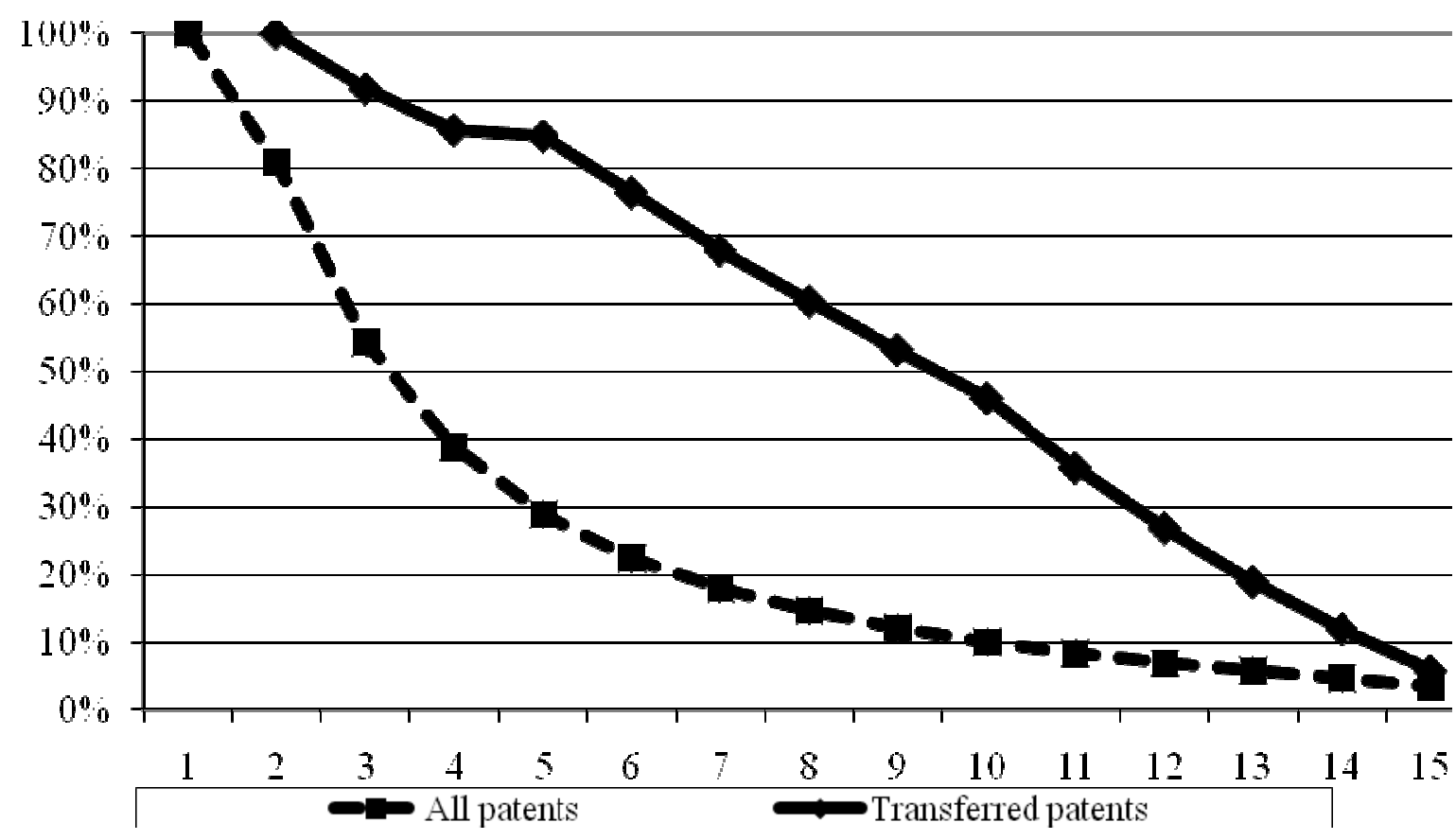

Figure 4: Survival rates during the years after issue of a patent. All patents versus transferred patents. Source: Patent transfer data base for the transferred patents; Kaiserliches Patentamt (1914: 83) and Reichspatentamt (1930: 77) for all patents.

Moreover, historical patent transfer data from Germany show that the average value of transferred patents was higher than the value of non-transferred patents (see Figure 4). On average, patents granted between 1891 and 1913 had an average lifetime of 4.6 years, whereas patents granted and transferred during this period had an average lifetime of 7.7 years. Thus, the average lifetime of transferred patents was about two-thirds higher than the lifetime of the average patent. 


\begin{tabular}{|c|c|c|c|c|c|c|}
\hline & $\begin{array}{l}\text { PANEL A: First- } \\
\text { round transfers } \\
(n=4,025)\end{array}$ & Firm & Individual & $\begin{array}{c}\text { New firm } \\
\text { ('entre-preneurial') }\end{array}$ & $\begin{array}{l}\text { Same firm or indi- } \\
\text { vidual, but differ- } \\
\text { ent legal form / } \\
\text { same family name } \\
\text { (inheritence) }\end{array}$ & Total \\
\hline & Firm & $15 \%$ & $9 \%$ & & $9 \%$ & $33 \%$ \\
\hline & Individual & $31 \%$ & $22 \%$ & $8 \%$ & $6 \%$ & $67 \%$ \\
\hline \multirow{5}{*}{$\begin{array}{l}\text { Origin of } \\
\text { the patent }\end{array}$} & Total & $46 \%$ & $31 \%$ & $8 \%$ & $15 \%$ & $100 \%$ \\
\hline & $\begin{array}{l}\text { PANEL B: Sec- } \\
\text { ond-round trans- } \\
\text { fers }(n=1,515)\end{array}$ & Firm & Individual & $\begin{array}{c}\text { New firm } \\
\text { ('entrepreneurial') }\end{array}$ & $\begin{array}{l}\text { Same firm or indi- } \\
\text { vidual, but differ- } \\
\text { ent legal form / } \\
\text { same family name } \\
\text { (inheritance) }\end{array}$ & Total \\
\hline & Firm & $38 \%$ & $13 \%$ & & $12 \%$ & $63 \%$ \\
\hline & Individual & $17 \%$ & $13 \%$ & $3 \%$ & $4 \%$ & $37 \%$ \\
\hline & Total & $55 \%$ & $26 \%$ & $3 \%$ & $16 \%$ & $100 \%$ \\
\hline
\end{tabular}

Source: Patent transfer database; own calculation.

Now, we turn to the participants in patent transfers (Table 1, Panel A). For a sub-sample of 4,025 patents, the name of the original patent owner was collected to find out whether a patent was issued to a firm or an individual. If two individuals or two firms involved in the two sides of the patent transfer bear the same name, we coded such a transaction as changes in legal form or inheritance. It turned out that 31 percent of all patents were transferred from individual inventors to 'established' firms, not bearing the name of the individual inventor; 22 percent to other individuals with a different family name, 6 percent to individuals bearing the same family name, and 8 percent to a firm bearing the name of the individual. This latter type of transfer was classified as 'entrepreneurial'. The remaining transferred patents originated in firms and were transferred to other firms ( 15 percent), to individuals ( 9 percent), and to a firm with the same name, but different legal form (9 percent). In summary, we observe a substantial transfer of patents from individual inventors to firms. Moreover, only one-third of all transferred patents originated from firms, but two-thirds of all transferred patents ended-up in firms. This finding is similar to a result derived by Lamoreaux / Sokoloff (1999: 32) using U.S. data for 1870/ 71, 1890/ 91, and 1910/ 11. In the U.S., all patents were issued to individuals, but 39 percent of all transfers of patents after issue were transfers from individuals to firms.

In addition, we collected information about the names of firms and persons offering and receiving patents in 1,515 second-order transfers, i.e., the transfer of a patent which was already transferred before (Table 1, Panel B). The second round of transfers is more clearly dominated by firms: 63 percent of these patents originated in firms (compared to 33 percent in the 
first round) and 70 percent ended up in firms (compared to 63 percent in the first round). In the second round, 38 percent of transactions are from one firm to another, 12 percent are changes related to changes in the legal form of an enterprise, and 13 percent refer to the transfer of a patent from a firm to an individual. Individuals, on the other hand, transferred patents to established firms (17 percent), to entrepreneurial firms (3 percent), to other individuals (13 percent), or as an inheritance (4 percent).

In Table 2, we track the structure of transactions over time by breaking the whole period into three equally long sub-periods: 1884-1893 (Table 2, Panel A), 1894-1903 (Table 2, Panel B), and 1904-1913 (Table 2, Panel C). It turns out that firm-to-firm transfers became more important over time, whereas individual-to-individual transfers declined. The share of firm-to-firm transfers increased from 10 percent during 1884-93 to 19 percent between 1904 and 1913, whereas the share of individual-to-individual transfers declined from 26 percent during 188493 to about 21 percent thereafter. Moreover, the share of transfers from individual inventors to firms first increased from 34 percent during 1884-93 to 38 percent during 1894-1903 before it declined to 22 percent during 1904-13. Furthermore, transfers related to entrepreneurial activity declined from 9 percent during $1884-93$ to only 6 percent during 1904-13. In summary, firms became more important over time. Between 1884 and 1893, 24 percent of all patents originated in firms and 62 percent of the patents ended-up in firms. Between 1904 and 1913, firms offered 43 percent of all patents and received 61 percent of them. Thus, supply and demand of patents increasingly became a B2B activity. This development mirrors the decline of the Schumpeterian inventor demonstrated by Lamoreaux and Sokoloff (2005) for the U.S. at the turn of the $20^{\text {th }}$ century. 


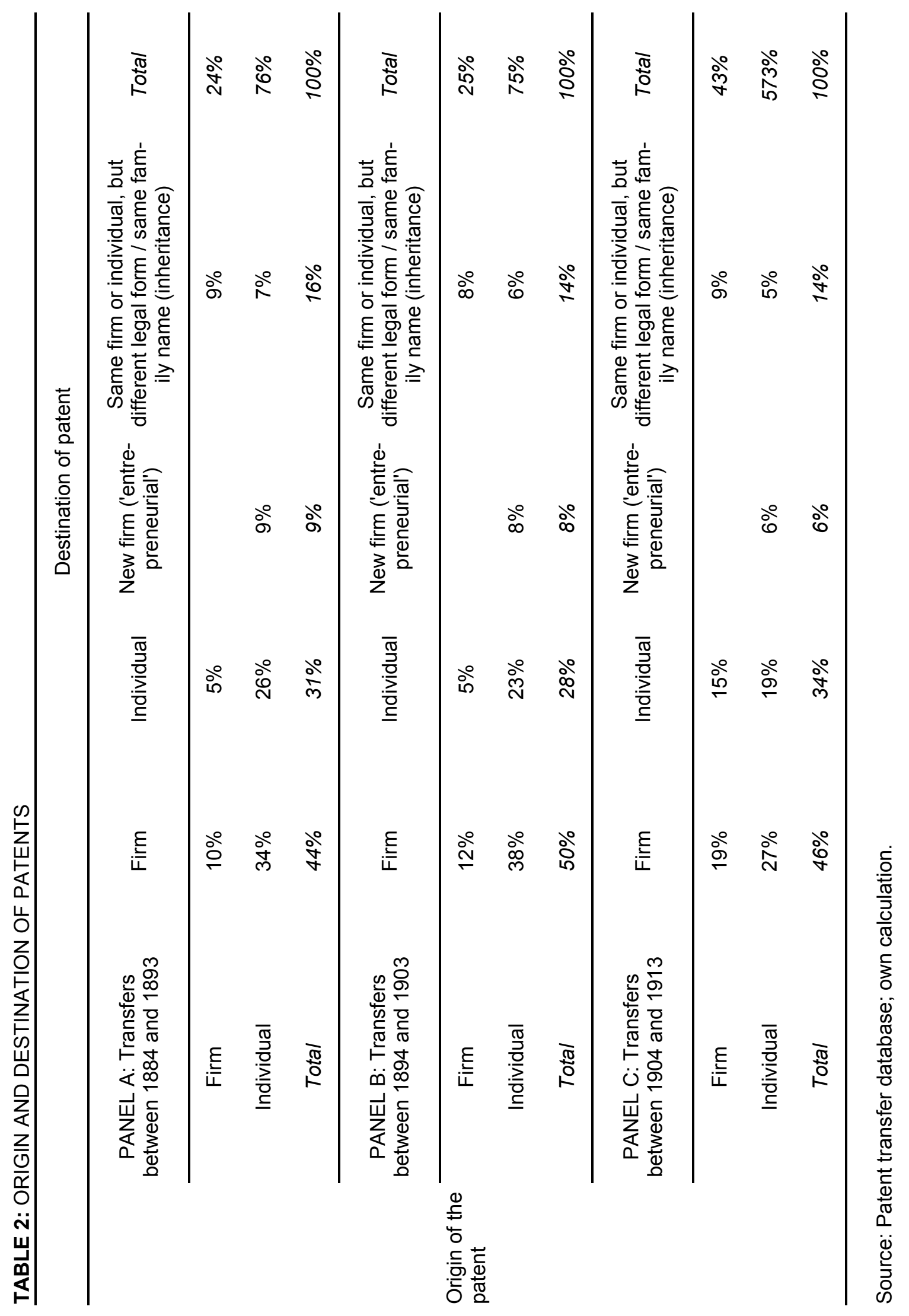




\section{Econometric evaluation}

The microeconomic patent transfer model proposed by Serrano (forthcoming) offers several hypotheses that can be confronted with the available historical data. Serrano extends the seminal patent renewal model proposed by Schankerman and Pakes (1986). In their model, the owner of a patent is faced with the choice between renewing and not renewing the patent for another period of protection. Extending the protection comes at the cost of the renewal fee, whereas not extending the protection implies forgoing potential future monopoly profits. A patent owner will extend the protection if the expected return is higher than the fees. Serrano extends this model by a third dimension: selling the patent to another person. Obviously, the buyer of the patent must differ in some respect form the seller of the patent, i.e., by having different expectations regarding the future profits or by owning different complementary assets to exploit the patent. A main prediction of this model is a negative relationship between the age of a patent and its trading probability. Intuitively, a newer patent offers a longer period of monopoly protection and should thus be more valuable on average. In addition, a classical lemons problem could occur on the patent market: why should an inventor sell a valuable patent instead of exploiting it himself? Thus, only lemons might be offered by inventors and the patent market might break down. Serrano highlights one signalling mechanism to prevent market breakdown: a patent that was traded before was already screened by the market and should consequently have a higher quality than the average patent. In a way, however, this is a circular argument, since the second buyer of the patent might question the quality of a patent first acquired and then again sold by the first buyer.

We asses if the central assumption of Serrano's model is reflected in our historical data: are patents transferred to economic actors having better complementary assets to exploit the patent than the original owner? Since the set of complementary assets is unobserved, we make the additional assumption that firms have better complementary assets than individual inventors. Consequently, patents should be transferred from individual inventors to firms. We have presented evidence supporting this assumption in Tables 1 and 2. Moreover, firms might also transfer patents to other firms having better complementary assets resulting in a higher option value of the patent. In addition, a central prediction of Serrano's model is the positive signal of a past patent transfer: transferred patents were screened and the positive result of the screening process is a signal of the high quality of a patent.

To start with, we investigate the determinants of the probability of a patent being transferred at all. According to Serrano's model, more valuable patents and patents issued to agents lacking complementary assets to exploit the patent should be more likely to be transferred. ${ }^{13}$ Yet, a key variable, i.e., the value of a patent, is not known ex ante. Thus, we assume that all agents have

13 Similar investigations based on modern or historical data are unavailable. Khan (2005: 156) provides a probit estimation of the probability of a patent being assigned at issue, whereas we investigate the probability of a patent being assigned after issue. 
correct expectations over the patent value and that the true patent value is reflected in the cumulated patent fees paid during the lifetime of a patent.

Table 3 presents the results of a standard probit regression using a five percent random sample of all patents granted in 1890, 1900, and 1910. The dependent variable is a zero-one coded dummy variable taking the value of one if a patent was transferred during its lifespan and zero otherwise. Explanatory variables are the log of the cumulated patent fees paid over the lifetime of a patent; a dummy variable taking the value of one if the patent was granted to an individual inventor; a dummy variable taking the value of one if the patent was granted to more than one patentee (joint-patenting); a dummy variable taking the value of one if the patent was granted to a foreigner; a dummy variable taking the value of one if the patent was transferred during the third year of its existence; and dummy variables for each of the three cross-sections $(1890,1900$, 1910).

TABLE 3: PROBABILITY THAT A PATENT WAS TRANSFERRED

DEPENDENT VARIABLE: DUMMY VARIABLE TAKING THE VALUE OF ONE IF THE PATENT WAS TRANSFERRED

\begin{tabular}{lcccc} 
& \multicolumn{2}{c}{ Parameter estimates } & \multicolumn{2}{c}{ Marginal effects } \\
& Coefficient & p-value & Coefficient & p-value \\
\hline Log (Cumulated fees paid over the & 0.382 & 0.000 & 0.022 & 0.000 \\
lifetime of a patent) & -0.065 & 0.644 & -0.004 & 0.655 \\
Patentee is an individual & 0.255 & 0.176 & 0.018 & 0.259 \\
Patent was granted to more than one & -0.056 & 0.682 & -0.003 & 0.676 \\
patentee & 0.035 & 0.848 & 0.002 & 0.851 \\
Patent was granted to a foreigner & 1.022 & 0.000 & 0.091 & 0.000 \\
Patent is in 3 ${ }^{\text {rd }}$ year of protection & 0.861 & 0.000 & 0.076 & 0.000 \\
1890 Cross section dummy & -4.663 & 0.000 & -0.971 & 0.000 \\
1900 Cross section dummy & \multicolumn{5}{c}{0.185} \\
1910 Cross section dummy & \multicolumn{5}{c}{0.949} \\
\hline McFadden pseudo R & \multicolumn{5}{c}{$116.82(0.000)$} \\
Fraction correctly predicted & \multicolumn{5}{c}{1,558} \\
Chi-square test (p-value) & Number of observations
\end{tabular}

Method: Probit regression. Marginal effect for dummy variables is calculated as probability of $x=1$ less probability of $x=0$.

We expect that more valuable patents have a higher probability of being transferred. Furthermore, the German patent law prescribed the application of a patent within three years after grant. Thus, we expect a significantly higher transfer probability of patents during their third year of existence. Moreover, from the construction of the data, we expect a significantly lower trading probability for patents granted in 1900 and especially for those granted in 1910 since transfers are only registered until 1913. 
The results presented in Table 3 show that our econometric specification explains about 18.5 percent of the variation in the data and that close to 95 percent of the outcomes are correctly predicted. We find that more valuable patents have a higher transfer probability. An increase of the (correctly expected) patent value of one percent increases the probability of a patent being transferred by about 0.022 percent. Thus, the marginal effect has the correct sign and is statistically significant. However, the marginal effect is small, even if the jumps of the cumulated patent fees are large in percentage terms. For example, extending the patent protection from the third to the fourth year of protection increases the cumulated fees from 200 Mark to 350 Mark, i.e., by 75 percent. Thus, the probability of patent transfer increases by about 1.7 percent.

In contrast to our expectations, a patent granted to an individual inventor does not have a significantly higher transfer probability. In addition, the fact that a patent was issued to more than one patentee or to a foreigner did not affect the transfer probability. Finally - and as expected - patents issued in 1910 have a significantly lower transfer probability. This is, however, induced by the construction of the data and not by economic fundamentals.

Regression equations (1) and (2) formalize other basic insights of Serrano's model. Regressions (1) and (2) and the results presented in Tables 4 and 5 are based on information about transferred patents only. The dependent variable in regressions (1) and (2) is a measure of patent value. More specifically, we employ the amount of patent fees paid after the transfer of a patent as a proxy for its value. ${ }^{14}$ If a patent has a value for the acquiring agent, the agent will be willing to pay the patent fees to get monopoly profits or to keep the option for future monopoly profits.

A set of patent-specific dummy variables is used on the right-hand side of the regression. Dummy variables indicating if the transfer was firm-to-firm, firm-to-private, private-to-firm or entrepreneurial are used. From theory, we expect that patents transferred from an individual inventor to a firm or from one firm to another firm have a higher value than the average transferred patent since the patent should be transferred to an agent possessing better complementary assets. Thus, we expect a significantly positive regression coefficient. In addition, we expect that the coefficient related to an inheritance transfer is insignificant since this transfer is not motivated by an economic cause. On the other hand, patents transferred in course of the change of the legal type of enterprise should have a significantly higher value since the new type of enterprise typically has better economic characteristics, e.g., limited liability or easier access to finance. Moreover, we look at the geographic, cultural, and legal distance between the two parties by including a dummy variable taking the value of one if the patent was transferred to a foreign agent. Furthermore, we account for the overall legal security of patents by including the number of patent cases put to the courts during the year of transfer per 1,000 valid patents as an explanatory variable. A high number of court cases could indicate insecurity of patent rights and should thus have a negative impact of the value of transferred patents. Equations (1) and (2) show the regression equations: 
(1) $\mathrm{V}_{\mathrm{i}}=\mathrm{a}_{0}+\mathrm{b}^{\prime} \mathrm{x}_{\mathrm{i}}+\delta \mathrm{c}_{\mathrm{t}}+\mathrm{u}_{\mathrm{k}}+\varepsilon_{\mathrm{i}, \mathrm{t}}$

(2) $\mathrm{V}_{\mathrm{i}}=\alpha_{0}+\beta^{\prime} \mathrm{x}_{\mathrm{i}}+\gamma \mathrm{c}_{\mathrm{t}}+\mu_{\mathrm{i}, \mathrm{k}}+\lambda_{\mathrm{i}, \tau}+\rho_{\mathrm{i}, \mathrm{t}}$

In equations (1) and (2), $V_{i}$ is a the amount of patent fees in Marks paid for patent $i$ after the transfer. The vector of coefficients to be estimated using OLS (the fixed effects models) or GLS (the random effects models) is denoted by $b^{\prime}$ and $\beta$ ', respectively. The vector $\mathrm{x}_{\mathrm{i}}$ of explanatory variables includes the above mentioned patent specific dummy variables. Moreover, $\delta$ and $\gamma$ measure the effect of the number of patent court cases during the period $t$ of the patent transfer. The normally distributed error terms $\varepsilon_{\mathrm{i}, \mathrm{t}}$ and $\rho_{\mathrm{i}, \mathrm{t}}$ should be uncorrelated with the other righthand-side variables; otherwise, an instrumental variables estimator would be appropriate. ${ }^{15}$ Equation (1) is a standard random effects estimator with an overall constant term $\mathrm{a}_{0}$ and a technology-group specific disturbance term $u_{k}$. Equation (2) is a two-factor fixed effects model with an overall constant $\alpha_{0}$, a technology group specific fixed effect $\mu_{\mathrm{i}, \mathrm{k}}$ and a year-of-grant specific fixed effect $\lambda_{\mathrm{i}, \tau}$.

Table 4 displays the results of the regressions based on 4,014 observations of patents granted and transferred one time between 1884 and 1913 is employed. The regression results shows that our estimation approach yields a jointly significant result and explains about 37.6 percent of the variation in the data. Moreover, a Hausman test rejects the random effects model in favour of a fixed effects model. In addition, unreported likelihood ratio tests and F-tests show that a twofactor fixed effects model is superior to one-way fixed effects models or simple OLS without technology- and / or period specific fixed effects. Consequently, our interpretation focuses on the two-way fixed effects model.

15 A regression of the residuals of equations (1) and (2) on the explanatory variables of these regressions shows that the residuals and the right-hand side variables are uncorrelated. This suggests that an instrumental variables estimator is not necessary and that the coefficients are unbiased and consistent. 
DEPENDENT VARIABLE: FEES PAID AFTER TRANSFER, IN MARKS

\begin{tabular}{|c|c|c|c|c|}
\hline & \multicolumn{2}{|c|}{$\begin{array}{l}\text { Two-Way-Fixed effects } \\
\text { model }\end{array}$} & \multicolumn{2}{|c|}{ Random effects model } \\
\hline & Coefficient & $\mathrm{p}$-value & Coefficient & $p$-value \\
\hline Firm-to-firm transfer & 379.01 & 0.000 & 371.58 & 0.000 \\
\hline Private-to-firm transfer & 222.49 & 0.000 & 226.93 & 0.000 \\
\hline Firm-to-private transfer & 61.52 & 0.340 & 38.97 & 0.543 \\
\hline Inheritance & -150.38 & 0.036 & -144.30 & 0.043 \\
\hline Firm changing legal form & 341.69 & 0.000 & 328.13 & 0.000 \\
\hline Entrepreneurial & 392.66 & 0.000 & 381.79 & 0.000 \\
\hline Transfer to foreign owner & -27.90 & 0.481 & -29.10 & 0.460 \\
\hline $\begin{array}{l}\text { Court decisions per } 1,000 \text { valid pat- } \\
\text { ents during the year of transfer }\end{array}$ & -119.89 & 0.003 & -36.70 & 0.337 \\
\hline Constant & $1,184.38$ & 0.000 & $1,467.10$ & 0.000 \\
\hline Hausman-Test ( $p$-value) & \multicolumn{4}{|c|}{0.000} \\
\hline adjusted $R^{2}$ & \multicolumn{4}{|c|}{0.376} \\
\hline F-Test (p-value) & \multicolumn{4}{|c|}{0.000} \\
\hline Number of observations & \multicolumn{4}{|c|}{4,014} \\
\hline
\end{tabular}

Method: Two-way fixed effects OLS and random effects GLS, respectively. Based on all patents transferred one time during the period 1884 to 1913.

The constant shows that 1,184 Marks were paid as patent fees after the transfer for the average transferred patent. As expected from theory, if a patent was transferred from a firm to another firm or if a patent was transferred from an individual to a firm, another 379 Marks and 222 Marks, respectively, were paid. Patents were transferred to economic agents possessing better complementary assets to exploit the patent and this resulted into higher fee payments to keep up the monopoly option. Moreover, valuable patents were transferred if a firm changed its legal form or if an individual transferred a patent to a newly-established, entrepreneurial, firm. In the former case, 342 Marks were additionally paid as patent fees; in the latter case the additional amount of fees was 393 Marks. Moreover, a high ratio of court decisions regarding patent infringements during the year of transfer are correlated with lower patent fees paid for patents transferred during this year. This suggests that insecurity about property rights negatively affected the willingness to pay fees after the transfer. In addition, if a patent was transferred as an inheritance, the cumulated fees paid after inheritance were significantly lower than for the average transferred patent. This could indicate that the patent had no economic value and was only kept by the inventor out of curiosity. Finally, transfers to foreign owners and transfers from firms to individuals do not differ from the average patent transferred.

In Table 5, we test one of Serrano's main propositions, i.e. that the first transfer of a patent is a positive signal for the patent value. Consequently, patents that were transferred more than one time should have a higher value than patents that were only transferred once. We assess this hypothesis by adding a dummy variable taking the value of one if a patent was transferred more 
than one time. Furthermore, Serrano implicitly assumes that the screening of the buyer during the first round is the source of the positive signal. We test if different types of first-round transfers affect the screening quality by generating a set of interaction effects, i.e., we multiply the double transfer dummy with the dummies for firm-to-firm, firm-to-private etc. transfers. The results do not support Serrano's signalling theory. The dummy variable "Patent was transferred twice" is statistically insignificant and slightly negative. Moreover, all interaction effects are insignificant. On the other hand, the additional variables do not affect the point estimates for the variables included into our baseline specification (see Table 4). Thus, we cannot confirm that twice transferred patents were significantly more valuable than patents that were transferred only once.

TABLE 5: THE VALUE OF PATENTS: THE SECOND ROUND IMPACT DEPENDENT VARIABLE: FEES PAID AFTER TRANSFER, IN MARKS

\begin{tabular}{|c|c|c|c|c|}
\hline & \multicolumn{2}{|c|}{$\begin{array}{l}\text { Two-Way-Fixed effects } \\
\text { model }\end{array}$} & \multicolumn{2}{|c|}{$\begin{array}{c}\text { Two-Way-Fixed effects } \\
\text { model }\end{array}$} \\
\hline & Coefficient & $p$-value & Coefficient & $\mathrm{p}$-value \\
\hline Firm-to-firm transfer & 370.59 & 0.000 & 377.08 & 0.000 \\
\hline Private-to-firm transfer & 214.21 & 0.000 & 219.93 & 0.000 \\
\hline Firm-to-private transfer & 56.94 & 0.391 & 61.62 & 0.353 \\
\hline Inheritance & -170.18 & 0.020 & -150.27 & 0.037 \\
\hline Firm changing legal form & 337.66 & 0.000 & 343.63 & 0.000 \\
\hline Entrepreneurial & 390.27 & 0.000 & 401.56 & 0.000 \\
\hline Transfer to foreign owner & -28.70 & 0.468 & -27.78 & 0.491 \\
\hline Patent was transferred twice & -52.45 & 0.694 & 45.44 & 0.735 \\
\hline Firm-to-Firm and twice transferred & 178.21 & 0.454 & 91.41 & 0.701 \\
\hline Private-to-Firm and twice transferred & 204.00 & 0.296 & 115.03 & 0.556 \\
\hline Firm-to-private and twice transferred & 53.73 & 0.826 & -43.95 & 0.857 \\
\hline Inheritance and twice transferred & 650.57 & 0.119 & & \\
\hline Entrepreneurial and twice transferred & & & -363.39 & 0.357 \\
\hline $\begin{array}{l}\text { Court decisions per } 1,000 \text { valid pat- } \\
\text { ents during the year of transfer }\end{array}$ & -122.62 & 0.002 & -123.22 & 0.002 \\
\hline Constant & $1,193.40$ & 0.000 & $1,188.49$ & 0.000 \\
\hline Adjusted $\mathrm{R}^{2}$ & \multicolumn{2}{|c|}{0.375} & \multicolumn{2}{|c|}{0.375} \\
\hline F-Test ( $p$-value) & \multicolumn{2}{|c|}{0.000} & \multicolumn{2}{|c|}{0.000} \\
\hline Number of observations & \multicolumn{4}{|c|}{4.014} \\
\hline
\end{tabular}

Method: Two-way fixed effects OLS. Based on all patents transferred during the period 1884 to 1913. 


\section{Conclusion}

After the enactment of the first unified German patent law in 1877, a substantial number of patents were transferred. Between 1884 and 1913, more than 18,000 patents were transferred at least once. This equals about 8.3 percent of all patents issued during this period. Consequently, the fraction of German patents transferred at the turn of the $20^{\text {th }}$ century was substantially smaller than the fraction of U.S. patents transferred during the same era, but nearly as high as in today's United States. In Germany, about two-thirds of the patent transfers were sealed during the first three years after issue of a patent and the patents transferred were - on average - substantially more valuable than the average patent issued in Germany during that period: the average lifetime of a transferred patent was about 7.7 years, whereas the mean lifetime of all patents was only 4.6 years. During the 1880 s transfers from individual inventors to firms dominated, whereas later on firm-to-firm transactions dominated. Therefore, we observe - like in the United States during the same period - the decline of the Schumpeterian individual inventor.

Furthermore, we can partly support Serrano's (forthcoming) patent transfer model. On the one hand, we show that transferred patents were more valuable than the average patent and that patents were often transferred to agents who were more likely in the possession of better complementary assets. Moreover, we show that the probability that a patent was transferred at all was slightly - increasing in its value. On the other hand, the first patent transfer cannot be taken as a positive signal for the quality of a patent, since the average quality of patents transferred only once and those transferred more than once was identical.

In summary, the emergence of patent transfers during the late $19^{\text {th }}$ - and early $20^{\text {th }}$ - century in Germany should have improved the allocation of technical knowledge in the economy. Consequently, the establishment of sound intellectual property rights in 1877 might have contributed to the rise of the modern industries forming the core of Germany's second industrial revolution at the turn of the $20^{\text {th }}$ century. Yet, this speculative hypothesis is left for future research based on the extensive data set described in the current article. 


\section{References}

Anand, B.T. and Khanna, T. (2000)

The structure of licensing contracts

Journal of Industrial Economics, 48, 103-135

Baten, J., Spadavecchia, A., Streb, J., and Yin, S. (2007)

What made south-western German firms innovative around 1900? Assessing the importance of intra- and inter-industry externalities

Oxford Economic Papers, 59, Special Issue, i105-i126

Burhop C. (2009)

Pharmaceutical research in Wilhelmine Germany: The case of E. Merck

Forthcoming, Business History Review

Burhop, C. and Lübbers, T. (2008)

Incentives and innovation? R\&D management in Germany's high-tech industries during the second industrial revolution

Max-Planck-Institute for Research on Collective Goods, Preprint 2008/38

Burhop, C. and Wolff, G.B. (2005)

A compromise estimate of German net national product, 1851-1913, and its implications for growth and the business cycle

Journal of Economic History, 65, 613-657

Cameron, R. and Nael, L. (2003)

A concise economic history of the world from Palaeolithic times to the present $4^{\text {th }}$ Edition, Oxford, Oxford University Press

Church, R. and Tansey, E.M. (2007)

Burroughs, Wellcome \& Co.: Knowledge, trust, profit, and the transformation of the British pharmaceutical industry

Crucible Books, Lancaster

Erker, P. (1990)

Zur Geschichte der Industrieforschung in den europäischen und amerikanischen

Elektrokonzernen, 1890-1930

Zeitschrift für Unternehmensgeschichte, 35, 73-94

Griliches, Z. (1990)

Patent statistics as economic indicators: A survey

Journal of Economic Literature, 28, 1661-1707

Grupp, H., Dominguez-Lacasa, I., and Friedrich-Nishio, M. (2002)

Das deutsche Innovationssystem seit der Reichsgründung

Physica-Verlag, Heidelberg

Hounshell, D.A. and Smith, K.A. (1988)

Science and corporate strategy: DuPont R\&D, 1902-1980

Cambridge University Press, Cambridge 
Kaiserliches Patentamt (various years)

Verzeichnis der im Jahre [...] ertheilten und noch in Kraft befindlichen Patente

Carl Heymann, Berlin

Kaiserliches Patentamt, Jahrbuch (1914)

Blatt für das Patent-, Muster- und Zeichenwesen, Vol. 20

Kaiserliches Statistisches Amt (various years)

Statistisches Jahrbuch für das Deutsche Reich

Carl Heymann, Berlin

Khan, Z.B. (1995)

Property rights and patent litigation in early nineteenth-century America

Journal of Economic History, 55, 58-97

Khan, Z.B. (2005)

The democratization of invention: Patents and copyrights in American economic development, 1790-1920

Cambridge University Press, Cambridge

Khan, Z.B. and Sokoloff, K.L. (1993)

"Schemes of practical utility": Entrepreneurship and innovation among "Great inventors" in the United States, 1790-1865

Journal of Economic History, 53, 289-307

Khan, Z.B. and Sokoloff, K.L. (2004)

Institutions and democratic invention in $19^{\text {th }}$-century America: Evidence from the

"Great Inventors", 1790-1930

American Economic Review, Papers \& Proceedings, 94, 395-401

König, W. (2007)

Wilhelm II und die Moderne: Der Kaiser und die technisch-industrielle Welt

Schöningh, Paderborn

Lamoreaux, N.R. and Sokoloff, K.L. (1999)

Inventors, firms, and the market for technology in the late nineteenth and early twentieth centuries

In: Lamoreaux, N.R. / Raff, D.M.G. / Temin, P. (Eds.), Learning by doing in markets, firms, and countries, University of Chicago Press, 1999, 19-60

Lamoreaux, N.R. and Sokoloff, K.L. (2000)

The geography of invention in the American glass industry, 1870-1925

Journal of Economic History, 60, 700-729

Lamoreaux, N.R. and Sokoloff, K.L. (2001)

Market trade in patents and the rise of a class of specialized inventors in the $19^{\text {th }}$-century

United States American Economic Review, Papers \& Proceedings, 91, 39-44

Lamoreaux, N.R. and Sokoloff, K.L. (2005)

The decline of the independent inventor: A Schumpeterian story

NBER Working Paper 11654 
Landes, D.S. (1999)

The wealth and poverty of nations. Why some are so rich and some so poor

W.W. Norten \& Co., New York

Lübbers, T. (2009)

Patentstatistiken als wirtschaftshistorische Quelle: Die Rechtssicherheit von deutschen

Patenten zwischen 1877 und 1913

Unpublished Working Paper, Max Planck Institute for Research on Collective Goods

Merck Record Office R 1/42

Anstellungsverträge und Erfinderverträge

Metz, R., and Watteler, O. (2002)

Historische Innovationsindikatoren: Ergebnisse einer Pilotstudie

Historical Social Research, 27, 4-129

Mowery, D.C. (1983)

The relationship between intrafirm and contractual forms of industrial research in

American manufacturing, 1900-1940

Explorations in Economic History, 20, 351-374

Murmann, J.P. (2006)

Knowledge and competitive advantage

Cambridge University Press, Cambridge

Nicholas, T. (2009)

Spatial diversity in invention: Evidence from the early R\&D labs

Journal of Economic Geography, 9, 1-31

Reichspatentamt (1930)

Blatt für das Patent-, Muster- und Zeichenwesen, Vol. 36

Serrano, C.J. (forthcoming)

The dynamics of the transfer and renewal of patents

Forthcoming, RAND Journal of Economics

Available as NBER Working Paper 13938

Schankerman, M. and Pakes, A. (1986)

Estimates of the value of patent rights in European countries during the post-1950

period

Economic Journal, 96, 1052-1076

Seckelmann, M. (2006)

Industrialisierung, Internationalisierung und Patentrecht im Deutschen Reich, 1871-

1914

Vittorio Klostermann, Frankfurt am Main

Spulber, D.F. (2008)

Innovation and international trade in technology

Journal of Economic Theory, 138, 2008, 1-20 
Streb, J., Baten, J., and Yin, S. (2006)

Technological and geographical knowledge spillover in the German Empire, 18771914

Economic History Review, 59, 343-373

Streb, J., Wallusch, J, and Yin, S. (2007)

Knowledge spill-over from new to old industries: The case of German synthetic dyes and textiles (1878-1913)

Explorations in Economic History, 44, 203-223

Streb, J. and Baten, J. (2007)

Ursachen und Folgen erfolgreicher Patentaktivitäten im Deutschen Kaiserreich:

Ein Forschungsbericht

In: Walter, R. (ed.), Innovationsgeschichte, Steiner Verlag, Stuttgart, 249-275

Swann, J.P. (1988)

Academic scientists and the pharmaceutical industry

Johns Hopkins University Press, Baltimore

Wimmer, W. (1994)

"Wir haben fast immer was Neues": Gesundheitswesen und Innovation in der PharmaIndustrie in Deutschland, 1880-1935

Duncker \& Humblot, Berlin 


\section{Preprints 2009}

2009/25: Burhop C., Lübbers T., The Historical Market for Technology Licenses: Chemicals, Pharmaceuticals, and Electrical Engineering in Imperial Germany

2009/24: Engel C., Competition as a Socially Desirable Dilemma Theory vs. Experimental Evidence

2009/23: Morell A., Glöckner A., Towfigh E., Sticky Rebates: Rollback Rebates Induce Non-Rational Loyalty in Consumers Experimental Evidence

2009/22: Traxler C., Majority Voting and the Welfare Implications of Tax Avoidance

2009/21: Beckenkamp M., Engel C., Glöckner A., Irlenbusch B., Hennig-Schmidt H., Kube S., Kurschilgen M., Morell A., Nicklisch A., Normann H., Towfigh E., Beware of Broken Windows! First Impressions in Public-good Experiments

2009/20: Nikiforakis N., Normann H., Wallace B., Asymmetric Enforcement of Cooperation in a Social Dilemma forthcoming in: Southern Economic Review, In Press.

2009/19: Magen S., Rechtliche und ökonomische Rationalität im Emissionshandelsrecht

2009/18: Broadberry S.N., Burhop C., Real Wages and Labour Productivity in Britain and Germany, 1871-1938: A Unified Approach to the International Comparison of Living Standards

2009/17: Glöckner A., Hodges S.D., Parallel Constraint Satisfaction in Memory-Based Decisions

2009/16: Petersen N., Review Essay: How Rational is International Law? forthcoming in: European Journal of International Law, vol. 20, In Press.

2009/15: Bierbrauer F., On the legitimacy of coercion for the financing of public goods

2009/14: Feri F., Irlenbusch B., Sutter M., Efficiency Gains from Team-Based Coordination - Large-Scale Experimental Evidence

2009/13: Jansen J., On Competition and the Strategic Management of Intellectual Property in Oligopoly

2009/12: Hellwig M., Utilitarian Mechanism Design for an Excludable Public Good published in: Economic Theory, vol. 2009, no. July 14, Berlin/Heidelberg, Springer, 2009.

2009/11: Weinschenk P., Persistence of Monopoly and Research Specialization

2009/10: Horstmann N., Ahlgrimm A., Glöckner A., How Distinct are Intuition and Deliberation? An Eye-Tracking Analysis of Instruction-Induced Decision Modes

2009/09: Lübbers T., Is Cartelisation Profitable? A Case Study of the Rhenish Westphalian Coal Syndicate, 1893-1913

2009/08: Glöckner A., Irlenbusch B., Kube S., Nicklisch A., Normann H., Leading with(out) Sacrifice?

A Public-Goods Experiment with a Super-Additive Player

forthcoming in: Economic Inquiry, In Press.

2009/07: von Weizsäcker C., Asymmetrie der Märkte und Wettbewerbsfreiheit

2009/06: Jansen J., Strategic Information Disclosure and Competition for an Imperfectly Protected Innovation forthcoming in: Journal of Industrial Economics, In Press.

2009/05: Petersen N., Abkehr von der internationalen Gemeinschaft? - Die aktuelle Rechtsprechung des US Supreme Court zur innerstaatlichen Wirkung von völkerrechtlichen Verträgen -

forthcoming in: Völkerrecht im innerstaatlichen Bereich, Vienna, facultas.wuv, In Press.

2009/04: Rincke J., Traxler C., Deterrence Through Word of Mouth 
2009/03: Traxler C., Winter J., Survey Evidence on Conditional Norm Enforcement

2009/02: Herbig B., Glöckner A., Experts and Decision Making: First Steps Towards a Unifying Theory of Decision Making in Novices, Intermediates and Experts

2009/01: Beckenkamp M., Environmental dilemmas revisited: structural consequences from the angle of institutional ergonomics, issue 2009/01

\section{Preprints 2008}

2008/49: Glöckner A., Dickert S., Base-rate Respect by Intuition: Approximating Rational Choices in Base-rate Tasks with Multiple Cues

2008/48: Glöckner A., Moritz S., A Fine-grained Analysis of the Jumping to Conclusions Bias in Schizophrenia: DataGathering, Response Confidence, and Information Integration

2008/47: Hellwig M., A Generalization of the Atkinson-Stiglitz (1976) Theorem on the Undesirability of Nonuniform Excise Taxation

2008/46: Burhop C., The Underpricing of Initial Public Offerings in Imperial Germany, 1870-1896 forthcoming in: German Economic Review, In Press.

2008/45: Hellwig M., A Note on Deaton's Theorem on the Undesirability of Nonuniform Excise Taxation forthcoming in: Economics Letters, In Press.

2008/44: Hellwig M., Zur Problematik staatlicher Beschränkungen der Beteiligung und der Einflussnahme von Investoren bei großen Unternehmen published in: Zeitschrift für das gesamte Handelsrecht und Wirtschaftsrecht, vol. 172, pp. 768-787, 2008.

2008/43: Hellwig M., Systemic Risk in the Financial Sector: An Analysis of the Subprime-Mortgage Financial Crisis published in: De Economist, no. 16.07.2009: Springer US, 2009.

published in: Jelle Zijlstra Lecture, no. 2008/5, Wassenaar, NL, Netherlands Institute for Advanced Study in the Humanities and Social Sciences, Institute of the Royal Netherlands Academy of Arts and Sciences, pp. 100, 2008.

2008/42: Glöckner A., Herbold A., Information Processing in Decisions under Risk: Evidence for Compensatory Strategies based on Automatic Processes

2008/41: Lüdemann J., Magen S., Effizienz statt Gerechtigkeit forthcoming in: Zeitschrift für Rechtsphilosophie, In Press.

2008/40: Engel C., Die Bedeutung der Verhaltensökonomie für das Kartellrecht

2008/39: Bierbrauer F., A unified approach to the revelation of public goods preferences and to optimal income taxation

2008/38: Burhop C., Lübbers T., Incentives and Innovation? R\&D Management in Germany's High-Tech Industries During the Second Industrial Revolution forthcoming in: Explorations in Economic History, In Press.

2008/37: Nicklisch A., Salz T., Reciprocity and status in a virtual field experiment

2008/36: Glöckner A., Engel C., Can We Trust Intuitive Jurors? An Experimental Analysis

2008/35: Lüdemann J., Wettbewerb und Regulierung in der Telekommunikation. Das Telekommunikationsrecht vor den Herausforderungen dynamischer Märkte

published in: Telekommunikation, Energie, Eisenbahn - Welche Regulierung brauchen die Netzwirtschaften?, Tübingen, Mohr Siebeck, pp. 69-99, 2008.

2008/34: Beckenkamp M., Playing strategically against nature? - Decisions viewed from a game-theoretic frame 